\title{
Neuromarketing from the perspective of a micro business
}

\section{Neuromarketing desde la perspectiva de un micronegocio}

\author{
ROMERO-ZARATE, Reynat, LÓPEZ-DE LA CRUZ, Mario and RÍOS-CARDENAS, Martín \\ Raymundo
}

ID $1^{\text {st }}$ Author: Reyna, Romero-Zarate / ORC ID: 0000-0002-8867-1989

ID $1^{\text {st }}$ Coauthor: Mario, López-De La Cruz / ORC ID: 0000-0001-6348-0994

ID $2^{\text {nd }}$ Coauthor: Martín Raymundo, Ríos-Cardenas / ORC ID: 0000-0002-5656-8944

DOI: $10.35429 /$ EJT.2019.6.3.18.23

Received October 22, 2019; Accepted December 11, 2019

\begin{abstract}
The micro-business are small enterprises which ones are characterized because they have 10 workers limited invoicing, due to low income, nevertheless, it's been calculated that in 2002 the $50 \%$ of the population in "Ciudad Nezahualcóyotl", México, was included in order to get economical resources in daily basis. The micro-enterprises in many occasions do not take into account to perform a marketing research to identify the characteristics (like real and trustable preference) of shoppers-costumers thinking it's irrelevant. The main purpose of this research was to aid the micro-entrepreneur to improve when taking decisions when buying supplies, applying, neuroscience and marketing technical analysis which ones have been refered in neuromarketing research.
\end{abstract}

Micro bussines, Investigation of market, Neurosciences, Marketing, Neuromarketing

\section{Resumen}

Los Micronegocios en México, son empresas muy pequeñas que se caracterizan porque tienen hasta 10 trabajadores y de facturación limitada, por los pocos ingresos que genera, sin embargo, se calcula que en 2002 el 50\% de la población en Ciudad Nezahualcóyotl, México, se conformaba de estos como forma para conseguir recursos económicos de manera recurrente. Los microempresarios en muchas ocasiones no consideran importante realizar investigación de mercado para identificar las características (como preferencias reales y confiables) de sus consumidores-compradores, por percibirlo como irrelevante. Con esta investigación se pretendió auxiliar al microempresario en mejorar la toma de decisiones en la compra de insumos aplicando técnicas de análisis de las neurociencias y de marketing, que han sido referidas en investigaciones de neuromarketing.

Micronegocios, Investigación de mercado, Neurociencias, Marketing, Neuromarketing.

Citation: ROMERO-ZARATE, Reyna, LÓPEZ-DE LA CRUZ, Mario and RÍOS-CARDENAS, Martín Raymundo. Neuromarketing from the perspective of a micro business. ECORFAN Journal-Taiwan. 2019 3-6: 18-23

$\dagger$ Researcher contributing as first author. 
Defining neuromarketing. Part of the Neurology is defined as "Part of the medicine that deals with the anatomy, physiology and pathology of the nervous system. It is the medical specialty that treats nervous system disorders. "Or" Part of the medicine that deals with the prevention, diagnosis, treatment and rehabilitation of diseases that involve the nervous system (central, peripheral and autonomous)".

From the neurology there are scientific fields that we know as neurosciences and we define them as "Field of science that is responsible for studying all aspects related to the Nervous System; from its structure, function, development (phylogenetic and ontogenetic), biochemistry, pharmacological applications, pathology, and how these different elements interact to give way to cognition and human behavior, mainly."

We mention some neurosciences that serve as a reference in the compression of your field of work: neuropharmacology, neuroendocrinology, neurosurgery, neuropathology, neuropsychiatry, neurobiology, neuropsychology and cognitive neuroscience that is based on a scientific study that unites disciplines such as neurobiology, psychobiology or cognitive psychology itself, studying the mental processes involved in behavior and its biological basis

Neuromarketing is the application of neuroscience techniques to traditional marketing research. It attempts to measure brain activity in its different aspects in the search for metric responses linked to emotions, moods, excitations and other unconscious responses that determine buying behavior. We will mention the main techniques used by neurosciences and their application:

Functional Magnetic Resonance Imaging (FMRI): doctors perform the FMRI to examine the functional anatomy of the brain, determine exactly the part of the brain that is controlling essential functions such as thinking, speech, movement and sensations, a process called brain mapping; evaluate the effects of a stroke, trauma or degenerative disease on the functioning of the brain; control the growth and functioning of brain tumors; Guide the planning of surgery, radiation therapy, or other invasive treatments of the brain.
Electroencephalography (EEG): A common technique with this technology is to measure the asymmetry of activity between the left and right regions of the frontal cortex (Davidson, Ekman et al., 1990). The scientific literature in this regard suggests that superior activity in the left region is associated well with positive emotional states, or with the intention of approaching an object (Harmon-Jones, 2003). In some cases, this technique has been used to measure momentary responses to television spots (Ohme, Reykowska et al., 2009; Ohme, Reykowska et al., 2010) although there is some controversy over whether it is necessary to make longer measurements, up to 60 seconds, to obtain results applicable with this technique (Hustler, Stevens et al., 2008).

The main advantage of the EEG over the FMRI is the cost, since equipment can be obtained for less than $\$ 10,000$.

The coordinated activity of neurons produces magnetic fields in addition to the electric currents measured by the EEG. The intensity of these fields is really small but can be measured by a technique called magnetoencephalography or MEG (Wikipedia, 2011c).

EEG and MEG are conceptually similar techniques, but MEG offers superior signal quality and a very high temporal resolution. However, its costs are much higher: a complete equipment including a magnetically insulated room can cost about 2 million dollars. Therefore, it is not a technique as popular as EEG among neuromarketing consulting agencies.

Electromyography or EMG is a medical technique that involves the application of small low-voltage electrodes in the form of needles in the muscular territory that you want to study to measure the response and connectivity between different electrodes; It measures electrical activity generated by the muscles, and neuromarketing consultants use it primarily to monitor facial muscles associated with involuntary emotional responses. When we are subjected to a stimulus (for example, a television commercial), the muscles of our face move involuntarily in reaction to what we are seeing. Some of these expressions are of very short duration and difficult to detect with the naked eye. 
The direct competence of this technique omits the use of measuring equipment giving input to less expensive processes and similar results as the one mentioned below.

Facial Action Coding System (FACS). It is not a technology in itself, but, in some cases, the observation of facial expressions is done by recording the subject's face and performing a manual coding of the muscles that are activated during exposure to the stimulus. The best known and used facial coding system was developed by Paul Ekman in the seventies (Ekman, Friesen, 1978). At present, there is computer software that allows the automatic coding of facial expressions (Azcarate, Hageloh et al., 2005; Salah, Sebe et al., 2009) and some companies market such software packages for use in market research.

We can find in Spain an interesting case of neuromarketing. Where the Neurobiomarketing agency, with offices in Milan and Barcelona, offers neuromarketing services internationally. Its measurement system (Mind Heart Eyes Hands) uses technologies such as EEG, eye-tracking or EDA recording to analyze the reactions of subjects to advertising spots (and other pieces). In collaboration with McCann Erickson Spain and Universal McCann they have created a database with the reactions of more than 400 subjects to different audiovisual pieces. Neurobiomarketing has several proprietary algorithms (patent pending) for the analysis of advertising pieces and they are continuously experimenting with different technologies.

\section{Qualitative research and organoleptic study}

Qualitative research provides information about motivations, inhibitions, thoughts, feelings, emotions and their reactions to certain products or services, the tools for collecting information are topic guides, observation guides.

Also called motivational studies, they study the true internal motives of the consumer so that they oril it to the purchase.

From the point of view of the psychological motivational field in the mechanism of buying any product there is a conflict between motivations and psychological phenomena, in the mind of the consumer;
Thus, when the motivation exceeds the brakes, the balance in the mind is broken and the subject is on the edge of the purchase or vice versa when the brakes exceed the motivations people do not buy.

Motivation is what is dormant internally (needs, desires) and tries to direct the behavior towards a specific end.

One of the limitations of qualitative research is that the results of cannot be projected to the universe, a mathematical rigor cannot be applied to qualitative research, some motivational researchers exaggerate in the use of "psychologisms" not providing clear and operational recommendations to Your clients.

As these are not revealed easily or exactly by consumers when they are directly questioned, motivational researchers use the resources of clinical psychology. One of the pioneers in qualitative or motivational research was Dr. Ernest Dichter - Viennese Psychoanalyst - who, in the 1950s, adapted his psychoanalytic techniques to the study of consumer buying habits in order to determine which were the motivators of the consumer.

Qualitative research covers aspects that quantitative research does not cover. The results of both types of research are not replaceable, but complementary. With qualitative research, the reason for the reaction of consumers, whether they are many or few, will be determined afterwards, through quantitative research. Qualitative research enriches the design of the instrument to be used in a quantitative phase.

Organoleptic tests: evaluate the physical characteristics of the product (color, smell, taste, texture, absorption, size, etc.) through the senses, in this type of test the product is tasted to be evaluated. Organoleptic tests represent the foundation of neuromarketing techniques, considering observations of the unhandled reaction of the market segment that is studied objectively.

"When we use techniques based on verbal statements to investigate certain especially sensitive issues (politics, sex ...), the consumer may be tempted to lie or respond using the stereotype of the right thing. Even if the consumer is willing to tell us the truth in his verbal statements, he may not know the answers we intend to obtain.

ROMERO-ZARATE, Reyna, LÓPEZ-DE LA CRUZ, Mario and RÍOS CARDENAS, Martín Raymundo. Neuromarketing from the perspective of a micro business. ECORFAN Journal-Taiwan 
According to most estimates, $95 \%$ of thoughts, emotions and learning occur at the unconscious level.

ZALTMAN, G. (2003): How Customers Think. Boston (MA), Harvard Business School Press, 40 The micro businesses in Ciudad Nezahualcoyotl (particular case)

In April 1963, the municipality of Ciudad Nezahualcóyotl was officially erected, representing the birth of municipality 120 for the State of Mexico, with limitations and deficiencies in public services was initially developed based on family work that was favored with the proximity and relative easy access to the Federal District, by $198560 \%$ of the companies located in the municipality were family members and therefore they entered the micro classification;

We have the data that in 2002 almost $51 \%$ of the operations of purchase and sale of products such as food, clothing, toys, tools and costume jewelery are mainly carried out in tianguis or informal street stalls which we give them the classification of micro businesses,

Objective. Evaluate the decision-making process in two market segments for a microbusiness of chopped fruit using an organoleptic technique which is the foundation of neuromarketing.

\section{Investigation}

The research was carried out in the three primary schools that represent the usual micro-business market, Francisco Gonzalez Bocanegra, Emiliano Zapata and Adolfo López Mateos. This market was divided into two groups of children where the distinguishing factor is being accompanied by their mothers, the first group consists of 464 children who choose their purchase without being directly accompanied by their mothers and the second group of 105 the latter Accompanied, approximately fifty percent of the portions were sold, counting the decisions was made since the decision from this point becomes biased when leaving the market with limited decision-making options.

An urban marketing conference was convened, which was attended by 127 young people between 18 and 21 years old students of the technological university of Nezahualcoyotl, they were offered a tasting of the product.

\section{Results}

Children from 7 to 9 years old

\begin{tabular}{|r|r|r|}
\hline Men & \multicolumn{1}{|c|}{ Women } & Total \\
\hline 37 & 68 & 105 \\
\hline
\end{tabular}

SEX
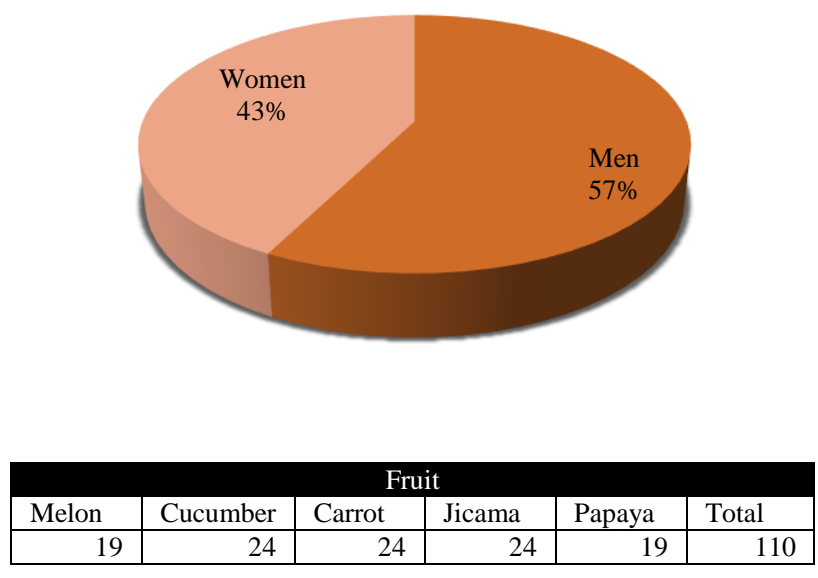

FRUIT

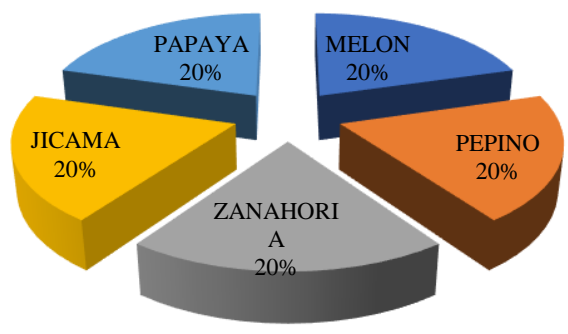

\begin{tabular}{|l|r|}
\hline \multicolumn{2}{|l|}{ Fist Elección } \\
\hline Melon & 14 \\
\hline Pepino & 19 \\
\hline Zanahoria & 6 \\
\hline Jicama & 4 \\
\hline Papaya & 15 \\
\hline & 58 \\
\hline
\end{tabular}

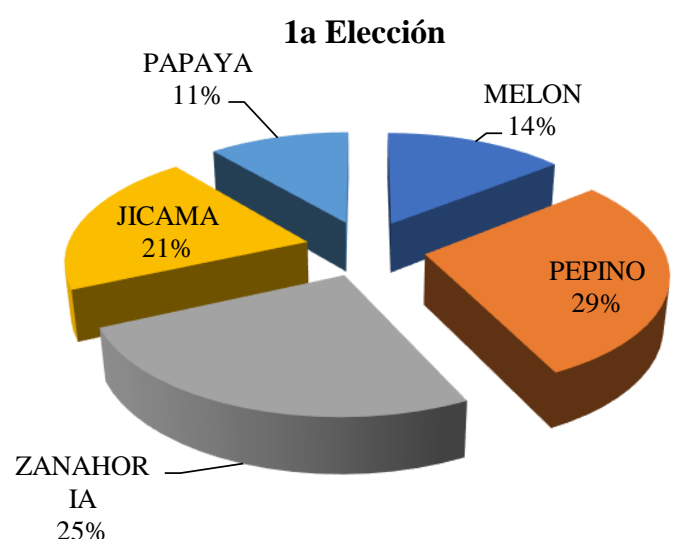

$25 \%$

ROMERO-ZARATE, Reyna, LÓPEZ-DE LA CRUZ, Mario and RÍOSCARDENAS, Martín Raymundo. Neuromarketing from the perspective of a micro business. ECORFAN Journal-Taiwan 


\begin{tabular}{|r|r|r|r|r|r|r|}
\hline \multicolumn{7}{|c|}{ Bittersweet } \\
\hline Blue & Purple & Pink & Orange & Yellow & Green & Colors \\
\hline 13 & 7 & 3 & 2 & 1 & 14 & 18 \\
\hline
\end{tabular}

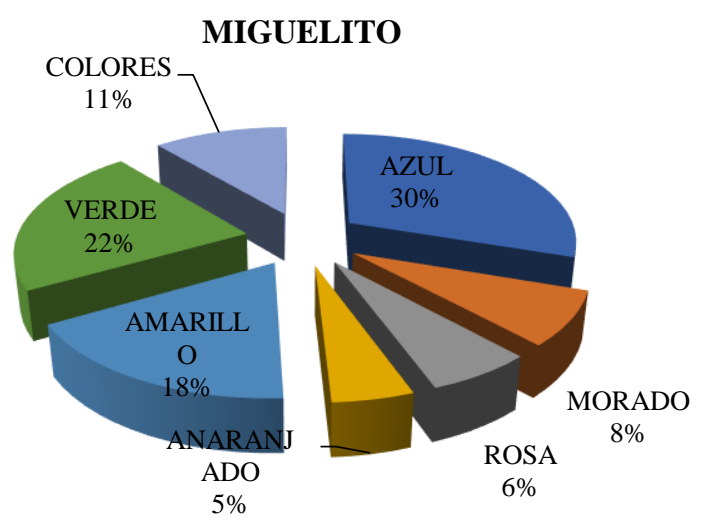

Niños de 7 a 11 años de edad sin compañía

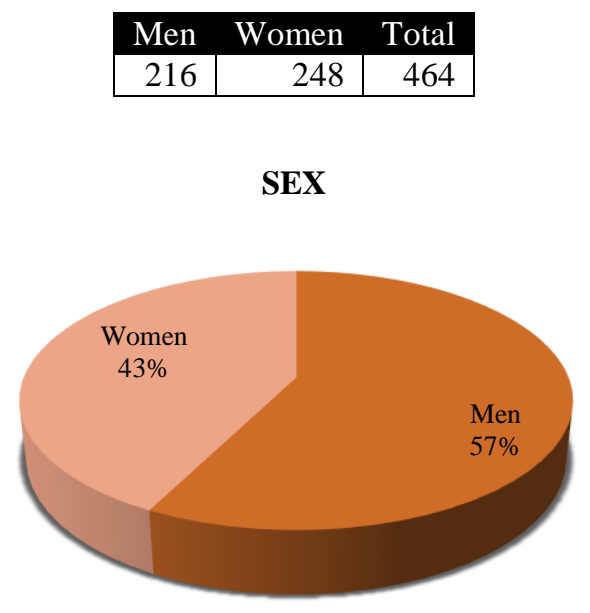

FRUIT

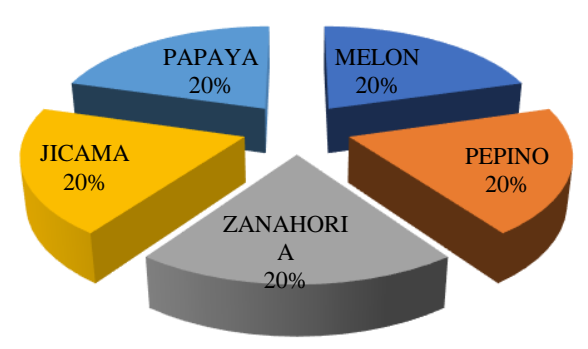

Fist Elección

\begin{tabular}{|l|r|}
\hline Melon & 42 \\
\hline Pepino & 62 \\
\hline Zanahoria & 48 \\
\hline Jicama & 53 \\
\hline Papaya & 33 \\
\hline & 238 \\
\hline
\end{tabular}
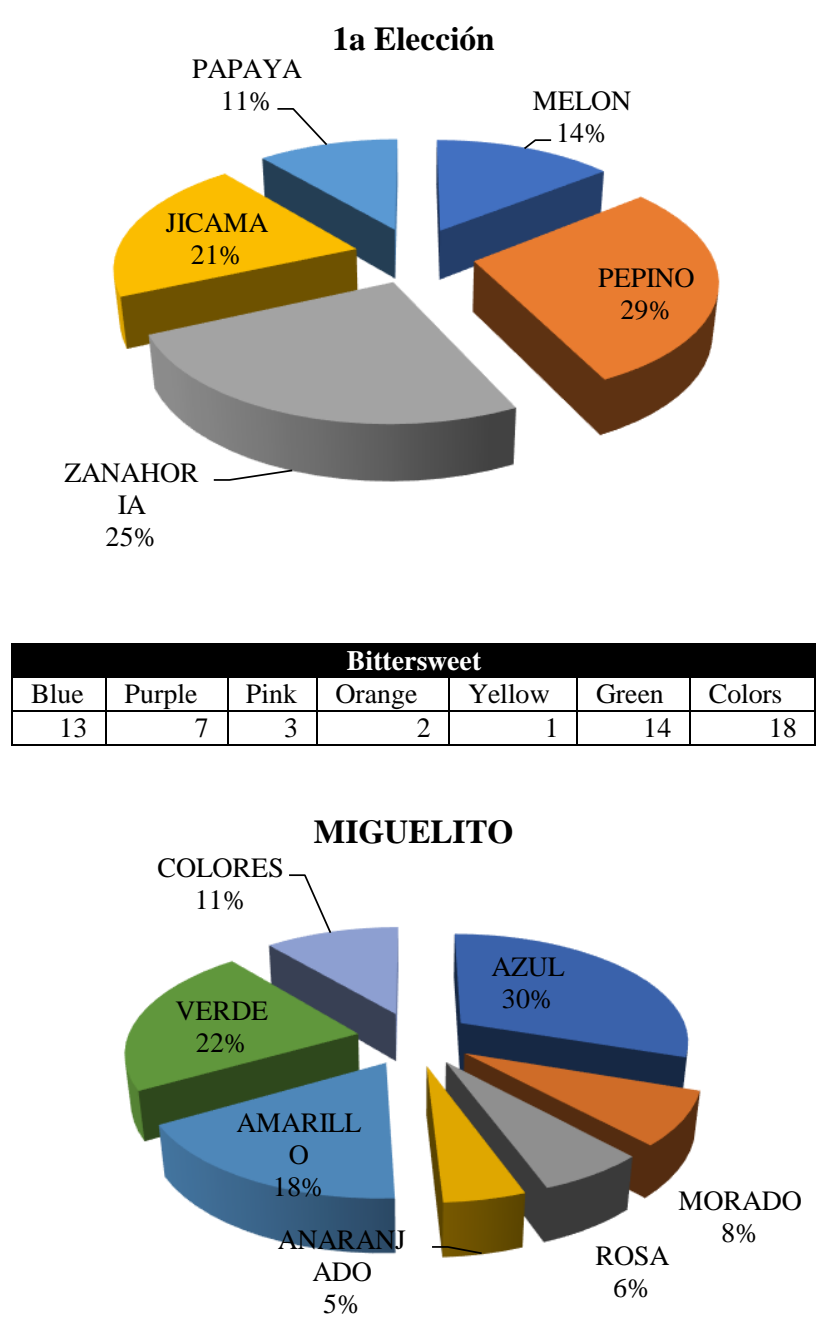

Jovenes de 18 a 21 años

\begin{tabular}{|r|r|r|}
\hline Men & Women & Total \\
\hline 73 & 54 & 127 \\
\hline
\end{tabular}

SEX

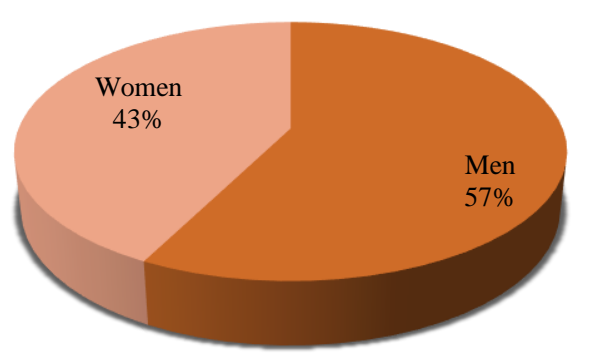




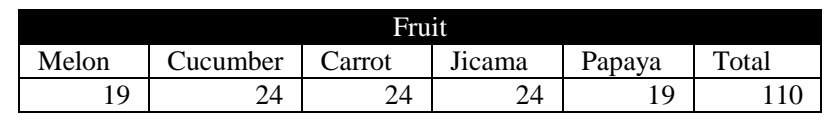

FRUIT
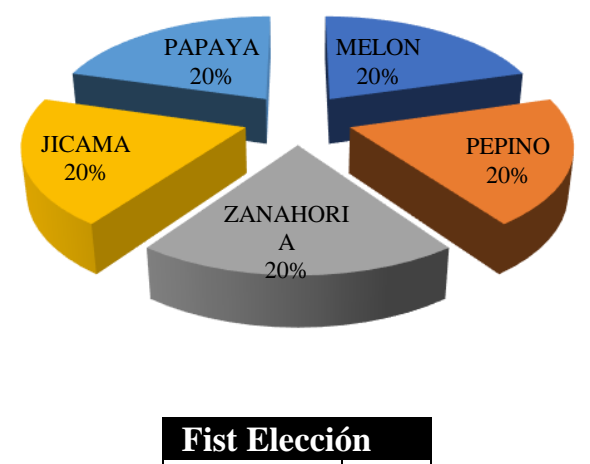

\begin{tabular}{|l|r|}
\hline Melon & 26 \\
\hline Pepino & 25 \\
\hline Zanahoria & 25 \\
\hline Jicama & 25 \\
\hline Papaya & 26 \\
\hline & 127 \\
\hline
\end{tabular}

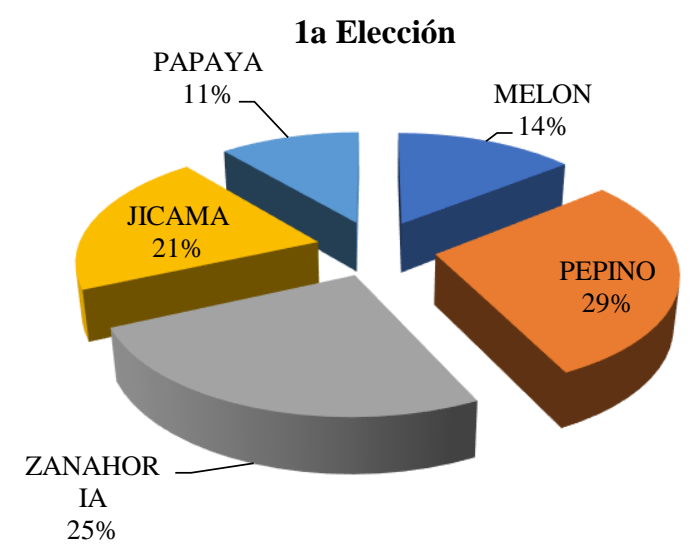

Bittersweet

\begin{tabular}{|c|l|l|l|l|l|l|}
\hline \multicolumn{7}{|c|}{ Bittersweet } \\
\hline Blue & Purple & Pink & Orange & Yellow & Green & Colors \\
\hline & & & & & & \\
\hline
\end{tabular}

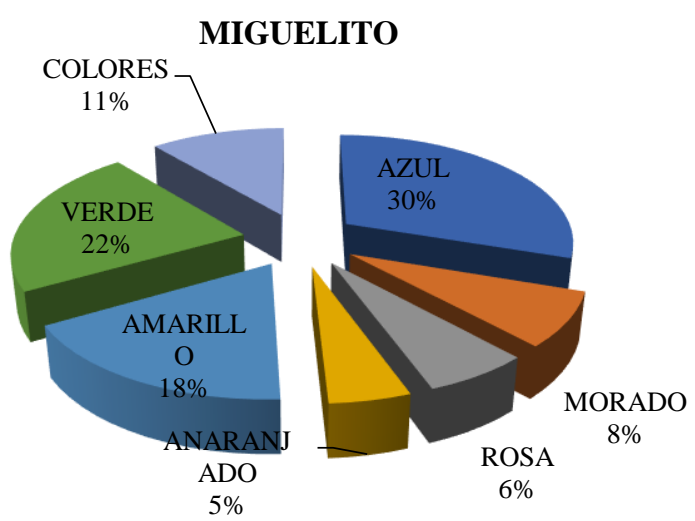

\section{References}

Domingo Anzizu, Roger (2009). Neuromarketing o como llegar a la mente del consumidor, España, ediciones deusto.

Braidot, Nestor, (2009) Neuromarketing ¿Por qué tus clientes se acuestan con otro si dicen que les gustas tú?, España, editorial Gestión 2000 .

Monge Benito, Sergio (2011) Neuromarketing: Tecnologías, Mercado y Retos, España, Universidad del País Vasco / Euskal Herriko Unibertsitatea

División de Comercialización (2002) Perfil mercadológico de Cd. Nezahualcóyotl 2002, México, Universidad Tecnológica de Nezahualcóyotl. 